\title{
Evalution of the Patients with Colon Polyps in Terms of Helicobacter pylori with Sydney Criteria
}

\section{Kolon Polibi Saptanan Hastaların Sydney Kriterleri Eşliğinde Helicobacter pylori Açısından İrdelenmesi}

\author{
(1) Çağrı Akalın1, (1) Özlem Özdemir2 \\ 1Ordu University Training and Research Hospital, Clinic of General Surgery, Ordu, Turkey \\ 2Ordu University Training and Research Hospital, Clinic of Internal Medicine, Ordu, Turkey
}

\section{|IIIIIII| ABSTRACT}

Aim: Colorectal cancer (CRC) is one of the leading three cancers with high mortality. Colon polyps are precursors for CRC development. Helicobacter pylori is known to increase the risk of gastric cancer by intestinal metaplasia (IM) and glandular atrophy (GA), there are studies suggesting that it increases the risk of CRC by various mechanisms. Sydney criteria have been developed to provide a standardized approach to histopathological changes in gastric mucosa caused by H. pylori. The aim of this study was to evaluate H. pylori according to the Sydney criteria in patients with colon polyps and to contribute to the literature.

Method: The study cohort included a control group ( $\mathrm{n}=231$ ) with normal colonoscopy findings and a patient group ( $\mathrm{n}=600$ ) who underwent upper gastrointestinal endoscopy and colonoscopy on the same day and had hyperplastic polyps, adenomatous polyps and malignant polyps. Age, gender, complications during endoscopy, number and localization of polyps, and histopathological results of gastric and colon biopsies were analyzed. The relationship between H. pylori, IM and GA and colon polyps were investigated with logistic regression model.

Results: H. pylori was present in 609 (73.3\%) of 831 patients. There was no statistically significant relationship between coexistence of H. pylori + IM and hyperplastic polyp and adenomatous polyp ( $\mathrm{p}>0.05$ ). It was found that IM did not increase the risk of CRC without $H$. pylori ( $\mathrm{p}=0.15)$. There was a statistically significant relationship between CRC and H. pylori + IM ( $\mathrm{p}=0.03)$. GA was detected in 70 patients ( $8.4 \%)$, and there was a statistically significant relationship between the presence of GA and CRC, regardless of the presence of H. pylori $(\mathrm{p}<0.05)$.

Conclusion: The results of the study showed that the coexistence of $H$. pylori and IM did not increase the risk of colon hyperplastic polyps, adenomatous polyps, but increased the risk of malignant polyps. There was also a statistically significant relationship between colon malignant polyps in the presence of GA regardless of the presence of H. pylori. In the light of the data obtained in the study, patients with $H$. pylori and IM and patients with GA should be followed up more closely for malignant colon polyps.

Keywords: Helicobacter pylori, Sydney criteria, colon polyps, glandular atrophy, intestinal metaplasia

\section{|||||||||| ÖZ}

Amaç: Kolorektal kanserler (KRK) yüksek mortaliteyle seyreden ilk 3 kanserden biridir. Kolon polipleri KRK gelişimi için prekürsordür. Helicobacter pylori'nin intestinal metaplazi (IM) ve glandular atrofi (GA) ile mide kanseri riskini arttırdığı bilinmekte olup ve çeşitli mekanizmalarla KRK riskini artırdığına dair çalışmalar mevcuttur. H. pylori’nin gastrik mukozada meydana getirdiği histopatolojik değişikliklere standart bir yaklaşım getirmek için Sydney kriterleri geliştirilmiştir. Amacımız kolon polibi saptanan hastalarda Sydney kriterleri eşliğinde H. pylori’yi irdeleyip literatüre katkıda bulunmaktır.

Yöntem: Çalışmaya kolonoskopisi normal olan kontrol grubu (n=231) ile birlikte üst gastrointestinal endoskopisi ve kolonoskopisi aynı gün yapılıp histopatolojisinde hiperplastik polip, adenomatöz polip ve malign polip saptanan hastalar ( $\mathrm{n}=600)$ dahil edildi. Hastaların yaşı, cinsiyeti, endoskopi sırasındaki komplikasyonlar, polip sayısı ve lokalizasyonu, mide ve kolon biyopsilerinin histopatolojik sonuçları analiz edildi. H. pylori, İM ve GA'nın kolon polipleri ile ilişkisi lojistik regresyon modeli ile incelendi.

Bulgular: Çalışmada 831 hastanın 609'unda (\%73,3) H. pylori mevcuttu. H. pylori ve İM birlikteliğinde hiperplastik polip ve adenomatöz polip arasında istatistiksel olarak anlamlı ilişki saptanmamıştır ( $p>0,05)$. İM'nin H. pylori olmaksınızın KRK riskini artırmadığı saptanmış olup (p=0,15), H.

Address for Correspondence/Yazışma Adresi: Çağrı Akalın MD,

Ordu University Training and Research Hospital, Clinic of General Surgery, Ordu, Turkey

Phone: +90 5059443326 E-mail: dr.cagriakalin@gmail.com ORCID ID: orcid.org/0000-0003-3370-9879

Received/Geliş Tarihi: 25.01.2019 Accepted/Kabul Tarihi: 25.01.2019

${ }^{\oplus}$ Copyright 2019 by Turkish Society of Colon and Rectal Surgery

Turkish Journal of Colorectal Disease published by Galenos Publishing House. 
pylori + IM birlikteliği ile KRK arasında istatistiksel olarak anlamlı ilişki saptanmıştır (p=0,03). Hastaların 70'inde (\%8,4) atrofi saptanırken, H. pylori olup olmadığı fark etmeksizin, GA mevcudiyeti ile KRK arasında istatistiksel olarak anlamlı ilişki saptanmıştır $(\mathrm{p}<0,05)$.

Sonuç: Çalışma sonucunda H. pylori ve İM ile birlikteliğinde kolon hiperplastik polibi, adenomatöz polibi riskini arttırmadığını ancak malign polip riskini artırdığı saptandı. Ayrıca GA mevcudiyetinde, H. pylori varlığı fark etmeksizin, kolon malign polipleri arasında istatistiksel olarak anlamlı bir ilişki bulunmaktadır. Çalışmada elde edilen veriler ışığında H. pylori ve İM mevcut olan hastalar ile GA mevcut olan hastalar malign kolon polibi açısından daha yakın takip edilmelidir.

Anahtar Kelimeler: Helicobacter pylori, Sydney kriterleri, kolon polipleri, glandular atrofi, intestinal metaplazi

\section{Introduction}

Colorectal cancers (CRC) are one of the leading three common cancers in the world with high mortality. ${ }^{1}$ The environmental and genetic factors play a role in the pathogenesis of CRC and 95\% of CRC develop sporadically. Environmental factors play a role in sporadic forms, but not genetic factors. ${ }^{2}$ The precursor of the sporadic form is mostly adenomatous polyps; and rarely, CRC may also develop from hyperplastic polyps. ${ }^{3}$ Helicobacter pylori was detected in 1983 by Marschall and Warren ${ }^{4}$ in the gastric epithelium of patients with chronic active gastritis. This microorganism is gram (-), spiral-shaped and produces urease enzyme, and is involved in the etiology of diseases such as chronic gastritis, peptic ulcer, gastric carcinoma and gastric mucosaassociated lymphoid tumor., 5 The Sydney criteria were established in 1990, allowing us to histopathologically evaluate the response of gastric mucosa to H. pylori. In 1990, Sydney criteria were developed by a group of pathologists to provide a standardized approach to the histopathological changes caused by $H$. pylori in the gastric mucosa. In the revised criteria in 1994, chronic inflammation, neutrophil activity, glandular atrophy (GA), intestinal metaplasia (IM) and $H$. pylori intensity are evaluated and graded. ${ }^{7}$ Although H. pylori is known to increase the risk of gastric cancer through IM and GA, recent studies have also demonstrated its association with neurodegenerative diseases and ischemic heart disease. ${ }^{8} \mathrm{H}$. pylori is one of the agents causing more than $90 \%$ of cancers related to infections. ${ }^{9}$ In addition, there are studies showing that $H$. pylori increases the risk of CRC, as well as studies showing that it does not, and there is no definite consensus. ${ }^{10,11,12}$ The aim of our study was to evaluate the patients with colon polyps together with $H$. pylori according to Sydney criteria and to contribute to the literature.

\section{Materials and Methods}

The patients who underwent upper gastrointestinal system (GIS) endoscopy and colonoscopy in the general surgery and gastroenterology departments of 4 public hospitals in Ordu province between January 2014 and August 2018 were analyzed retrospectively. In this study, age, gender, complications during endoscopy (bleeding, perforation), number of polyps, localization of polyps (cecum, ascending colon, transverse colon, descending colon, sigmoid, rectum and anal canal), and histopathological results of stomach and colon biopsies were analyzed. Patients who underwent colonoscopic polypectomy and who had mucosal biopsy from the antrum, corpus, fundus or duodenum during simultaneous upper gastrointestinal endoscopy were included in this study. Patients under 18 years of age, patients with malignancy, inflammatory bowel disease, familial adenomatous polyposis, patients with suboptimal colon examination, patients with missing colon or gastric biopsy results, and patients who did not undergo endoscopy on the same day were excluded. The control group consisted of patients who underwent upper GIS endoscopy and had normal colonoscopy findings. Patient data were obtained from hospital data processing system and patient archive system.

Endoscopy procedures were performed by general surgery and gastroenterology specialists under sedation. Gastric biopsy contents were obtained from the corpus, antrum and suspicious localizations by the clinician performing the endoscopy. Colonoscopic polypectomy was performed piece-by-piece or totally by using forceps and snare. Polyps that could not be removed colonoscopically were either referred to a more advanced center or removed by surgical intervention. Colon and gastric pathology specimens were examined in the pathology laboratory of the hospital. Gastric specimens were evaluated histopathologically according to Sydney criteria for the presence of H. pylori, neutrophil activity, chronic inflammation, IM and GA. ${ }^{7}$ Pathological evaluation was between 0 and 3 (0. none, 1. mild, 2. moderate, 3. severe) for H. pylori, neutrophil activity, and chronic inflammation criteria, and as -/+ (-: negative, +: positive) for IM and GA. Colon specimens were classified as non-neoplastic (hyperplastic) and neoplastic (tubular, tubulovillous, villous, intramucosal carcinoma, adenocarcinoma) histopathologically. Patients with normal colonoscopy were named as control group, patients with hyperplastic polyp as hyperplastic group, patients with neoplastic adenomatous polyp as adenoma group, and patients with malignancy as malignancy group. Patients with both hyperplastic polyps and adenomatous polyps 
were included in the adenoma group, while patients with both adenomatous polyps and malignant polyps were included in the malignancy group. In addition, patients with intramucosal carcinoma histopathology were included in the malignancy group.

The study was carried out in accordance with the Helsinki Declaration 2008 principles. Descriptive statistics for continuous variables included mean, minimum and maximum values, and categorical variables were expressed as numbers and percentages. Chi-square test was used to compare categorical variables. Mann-Whitney U test was used for comparison of continuous data. One-way ANOVA was used for the correlation of Sydney criteria, including H. pylori intensity, activation and inflammation. Logistic regression analysis was used to compare the relationship between IM and GA, and CRC. P $<0.05$ was considered statistically significant. SPSS (IBM SPSS for Windows, Ver.24) statistical package program was used for analysis.

\section{Results}

The mean age of 831 patients in our study was $58.85 \pm 10.95$ (range, 26-88) years. Of the patients, 333 (40.1\%) were female and 498 (59.9\%) were male. There was no statistically significant difference between the groups in terms of age and gender $(p>0.05)$. Colon polyps were detected in 600 (72.2\%) patients, and no colonic polyps were detected in $231(27.8 \%)$ patients in the control group. The total number of polypectomy was 971 and the mean number of polyps per colonoscopy was 1.55 . There were no complications in 816 patients (98.2\%) during colonoscopy, while bleeding was seen during polypectomy in 15 patients (1.8\%). Bleedings stopped spontaneously without any intervention. There was no perforation during colonoscopy and no complication occurred during upper GIS endoscopy. The number of polypectomy performed during colonoscopy was minimum one and maximum eleven. Polyps could not be excised by colonoscopy in 24 patients. While 23 patients required surgical intervention, one patient underwent colonoscopic polypectomy in the advanced center. The histopathological results of these patients were adenocarcinomas in 18 patients, villous adenoma in five patients and tubulovillous adenoma in one patient. The number of polyps according to colonic localization was as follows: $37(3.8 \%)$ in cecum, $72(7.3 \%)$ in ascending colon, $136(15.1 \%)$ in transverse colon, 97 (10\%) in descending colon, $356(35 \%)$ in sigmoid colon, $273(27.7 \%)$ in rectum and $15(1.5 \%)$ in anal canal. Hyperplastic polyps were detected in 200 (24.1\%), adenomatous polyps in $371(44.6 \%)$ and malignant polyps in 29 (3.5\%) patients. Eight of the malignant polyps were interpreted as intramucosal carcinoma and 21 of them were as colonic adenocarcinoma. There was no statistically significant relationship between histopathology and localization of polyps ( $>>0.05)$. Data regarding age, gender, number of polyps, localization and histopathology of the patients are given in Table 1. H. pylori was positive in 609 patients (73.3\%), while negative in 222 patients (26.7\%). H. pylori negativity/positivity ratio according to groups was

Table 1. Data on age, gender, number of polyps, localization and histopathology

\begin{tabular}{|c|c|c|c|c|c|c|}
\hline Variables & $\begin{array}{l}\text { Group } 1 \\
(n=231) \\
\text { (control) }\end{array}$ & $\begin{array}{l}\text { Group } 2 \\
(\mathrm{n}=200) \\
\text { (hyperplastic) }\end{array}$ & $\begin{array}{l}\text { Group } 3 \\
(\mathrm{n}=371) \\
\text { (adenoma) }\end{array}$ & $\begin{array}{l}\text { Group } 4 \\
(n=29) \\
\text { (malignant) }\end{array}$ & $\begin{array}{l}\text { Total } \\
(n=831)\end{array}$ & $\mathrm{p}$ \\
\hline Age (min-max) & $\begin{array}{l}56.97 \pm 10.48 \\
(31-79)\end{array}$ & $\begin{array}{l}58.16 \pm 11.11 \\
(30-78)\end{array}$ & $\begin{array}{l}60.54 \pm 10.69 \\
(26-88)\end{array}$ & $\begin{array}{l}61.97 \pm 11.92 \\
(39-86)\end{array}$ & $\begin{array}{l}59.03 \pm 10.89 \\
(26-88)\end{array}$ & $0.139 *$ \\
\hline $\begin{array}{l}\text { Gender } \\
\text { Female } \\
\text { Male }\end{array}$ & $\begin{array}{l}105 \\
126\end{array}$ & $\begin{array}{l}71 \\
129\end{array}$ & $\begin{array}{l}144 \\
227\end{array}$ & $\begin{array}{l}13 \\
16\end{array}$ & $\begin{array}{l}333 \\
498\end{array}$ & $0.169 * *$ \\
\hline $\begin{array}{l}\text { Polyp localization } \\
\text { Cecum } \\
\text { Ascending colon } \\
\text { Transverse colon } \\
\text { Descending colon } \\
\text { Sigmoid colon } \\
\text { Rectum } \\
\text { Anus }\end{array}$ & & $\begin{array}{l}7 \\
15 \\
25 \\
24 \\
117 \\
119 \\
9\end{array}$ & $\begin{array}{l}26 \\
54 \\
105 \\
69 \\
227 \\
140 \\
5\end{array}$ & $\begin{array}{l}3 \\
2 \\
3 \\
2 \\
8 \\
11 \\
-\end{array}$ & $\begin{array}{l}36 \\
71 \\
133 \\
95 \\
352 \\
270 \\
14\end{array}$ & $>0.05^{*}$ \\
\hline Total & & 316 & 626 & 29 & 971 & \\
\hline
\end{tabular}

Min: Minimum, Max: Maximum, *Mann-Whitney U test was used, **Chi-square test was used 
as follows: 65/166 in Group 1, 52/148 in Group 2, 100/271 in Group 3, and 5/24 in Group 4. There was no statistically significant relationship between $H$. pylori positivity and colon polyps ( $\mathrm{p}=0.65$ ). When the intensity of $H$. pylori was examined, $H$. pylori was negative in 215 patients (25.9\%), (+) in 367 patients $(44.2 \%),(++)$ in 231 patients $(27.8 \%)$ and $(+++)$ in 18 patients (2.2\%). There was no statistically significant relationship between $H$. pylori intensity and neoplastic status of colon polyps $(\mathrm{p}=0.65)$. Activation values of gastric biopsies were negative in 125 patients (15\%), (+) in 400 patients (48.1\%), (++) in 1261 patients $(31.4 \%)$ and $(+++)$ in 45 patients (5.4\%). Inflammation values were negative in 14 patients $(1.7 \%),(+)$ in 410 patients (49.3\%), (++) in 344 patients (41.4\%) and (+++) in 63 patients (7.6\%). According to the Sydney criteria, no significant correlation was found between $H$. pylori intensity, activation and inflammation and colon polyp neoplasms $(\mathrm{p}=0.65, \mathrm{p}=0.99, \mathrm{p}=0.31$, respectively). The neoplastic data and statistical data of the patients according to chi-square test of IM, GA and colon polyps are shown in Table 2. Although the relationship between IM and CRC patients was significant $(\mathrm{p}=0.003)$, Table 3 shows that IM was not a single risk factor in the presence of $H$. pylori and GA when evaluated by multiple logistic regression analysis. When the relationship between colon polyps and the presence of $H$. pylori, IM and GA were examined together, the data of the multiple logistic regression analyzes are shown in Table 3.
In the study, it was shown in Table 2 that IM was found to be proportionally high in patients compared to GA, and it was found that GA decreased proportionally less than IM in patients with CRC and that IM was more homogeneous in all patients than GA. Data showing the distribution between GA, IM and CRC is shown in Figure 1. In logistic regression analysis, when the IM and GA values of $H$. pylori negative patients were examined, no statistically significant relationship was found between CRC and IM ( $\mathrm{p}=0.15)$, and a significant relationship was found between CRC and GA $(\mathrm{p}=0.041)$.

\section{Discussion}

CRCs are an important cause of morbidity and mortality in the world, accounting for $9 \%$ of the incidence of cancer. ${ }^{13}$ Although multiple factors play a role in colon cancerogenesis, environmental factors constitute 95\% of this rate. ${ }^{14} \mathrm{H}$. pylori is a microorganism that is found in about $50 \%$ of the population and the rate increases to $80 \%$ in developing countries. ${ }^{15} \mathrm{H}$. pylori is a type of bacteria classified as Group 1 carcinogen and is in the same category as smoking and asbestos. ${ }^{16}$ The high rate of environmental factors in CRC and the fact that H. pylori is carcinogenic and common in the population has led to the necessity to investigate $H$. pylori in the etiology of CRC. In addition, in recent studies, the cultivation of some $\mathrm{H}$. species in the colon mucosa of patients with inflammatory bowel disease has

Table 2. Neoplastic information of colon polyps with intestinal metaplasia and atrophy parameters of Sydney criteria

\begin{tabular}{|c|c|c|c|c|}
\hline Variables & $\begin{array}{l}\text { Group } 1 \\
(\mathrm{n}=231) \\
\text { (control) }\end{array}$ & $\begin{array}{l}\text { Group } 2 \\
(\mathrm{n}=200) \\
\text { (hyperplastic) }\end{array}$ & $\begin{array}{l}\text { Group } 3 \\
(\mathrm{n}=371) \\
\text { (adenoma) }\end{array}$ & $\begin{array}{l}\text { Group } 4 \\
(\mathrm{n}=29) \\
\text { (malignant) }\end{array}$ \\
\hline Present & 35 & 29 & 58 & 11 \\
\hline Absent & 196 & 171 & 313 & 18 \\
\hline Absent & 223 & 184 & 334 & 20 \\
\hline
\end{tabular}

Table 3. Data regarding colon polyps and presence of hyperplastic polyps, intestinal metaplasia and atrophy

\begin{tabular}{|c|c|c|c|c|c|c|c|c|c|c|}
\hline & $\begin{array}{l}\text { HP } \\
\text { OR (95\% CI) }\end{array}$ & $\mathrm{p}^{*}$ & $\begin{array}{l}\text { T } \\
\text { OR (95\% CI) }\end{array}$ & $\mathrm{p}^{*}$ & $\begin{array}{l}\text { TV } \\
\text { OR (95\% CI) }\end{array}$ & $\mathrm{p}^{*}$ & $\begin{array}{l}\text { V } \\
\text { OR }(95 \% \text { CI })\end{array}$ & $\mathrm{p}^{*}$ & $\begin{array}{l}\text { M } \\
\text { OR }(95 \% \mathrm{CI})\end{array}$ & $\mathrm{p}^{*}$ \\
\hline HP & $0.95(0.66-1.36)$ & 0.76 & $1.12(0.81-1.53)$ & 0.50 & $0.88(0.51-1.51)$ & 0.63 & $2.78(0.59-13.13)$ & 0.20 & $0.66(0.24-1.77)$ & 0.40 \\
\hline $\begin{array}{l}\text { Intestinal } \\
\text { metaplasia }\end{array}$ & $0.85(0.52-1.41)$ & 0.53 & $0.85(0.55-1.31)$ & 0.46 & $1.07(0.54-2.12)$ & 0.84 & $1.48(0.19-11.46)$ & 0.71 & $1.86(0.72-4.86)$ & 0.20 \\
\hline Atrophy & $1.02(0.53-1.96)$ & 0.96 & $1.35(0.77-2.37)$ & 0.30 & $1.76(0.79-3.94)$ & 0.17 & $7.87(0.98-63.06)$ & 0.06 & 3.57 (1.29-9.89) & 0.02 \\
\hline
\end{tabular}

OR: Odds ratio, HP: Hyperplastic polyp, T: Tubular polyp, TV: Tubulovillous polyp, V: Villous polyp, M: Malignant polyp, CI: Confidence interval, *Logistic regression analysis was applied 


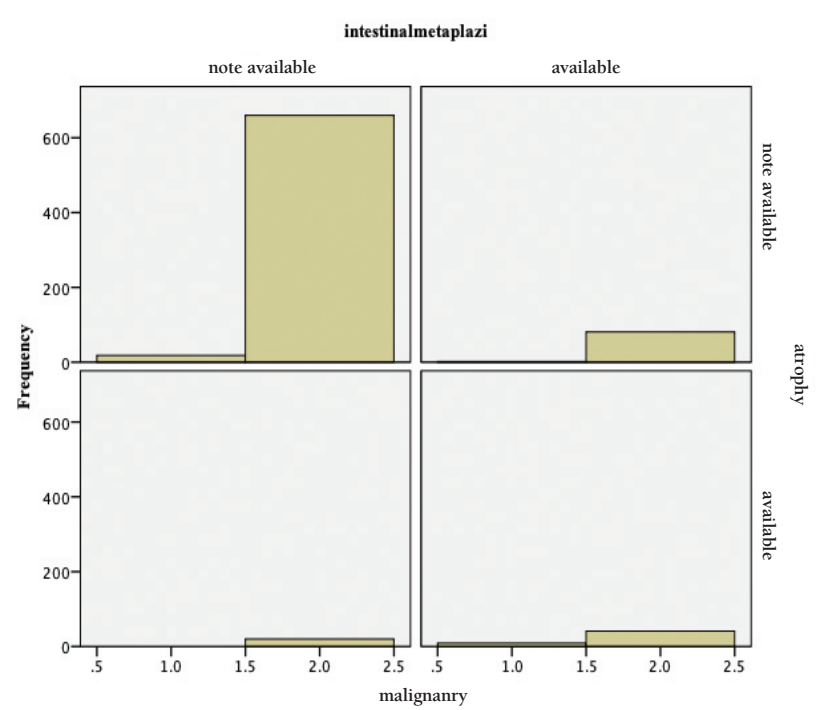

Figure 1. Information showing the distribution between glandular atrophy, intestinal metaplasia and colorectal cancer

aroused more interest between Helicobacter species and colon pathologies. ${ }^{17,18} \mathrm{H}$. pylori diagnosis can be made with noninvasive and invasive diagnostic methods and histological method, which is the gold standard method, was used in our study. ${ }^{19}$ This diagnostic method also gave us the advantage of examining the Sydney criteria with colon polyps, except for $\mathrm{H}$. pylori intensity. Buso et al. ${ }^{20}$ and Fujimori et al. ${ }^{21}$ found no significant relationship between the presence of H. pylori and CRC in women. We think that these clinical results are caused by gynecological hormones. In our study, no significant relationship was found between female gender and colon hyperplastic and adenomatous polyps, and adenocarcinoma. Fujimori et al..$^{21}$ and Brim et al..$^{22}$ found no significant relationship between the localization of $\mathrm{H}$. pylori and colorectal neoplastic polyps. In our study, we did not find any significant relationship between $H$. pylori and the localization of hyperplastic, adenomatous and malignant polyps. H. pylori has a virulence factor called cytotoxinassociated gene A (Cag-A), which can cause ulcers and cancer. There are studies stating that this factor is colonized in the gastric mucosa and leads to hypergastrinemia through long-term inflammation and leads to the risk of CRC. ${ }^{23}$ In a prospective study, Strofilas et al..$^{24}$ examined gastrin and Cag-A levels in 93 CRC patients, and found no significant relationship between CRC and H. pylori. Zhao et al. ${ }^{25}$ revealed a significant relationship between $H$. pylori and CRC in patients analyzed by Anti-H. pylori immunoglobulin G. In a case-control study by Wang et al. ${ }^{26}$, a significant relationship was found between Cag-A levels and CRC in 27 patients. They also found that the risk of tubular and villous adenomas was associated with increased Cag-A levels. In our study, a non-serological histological method was used for the diagnosis of $\mathrm{H}$. pylori and the result of our study was not consistent with the study of Wang et al. ${ }^{26}$ Sonenberg and Genta $^{27}$ examined simultaneous gastric and colon biopsies of 156.000 patients and found a significant relationship between $H$. pylori and hyperplastic polyps, adenomatous polyps, villous adenomas, and CRC. However, considering active gastritis patients as a result of upper GIS endoscopy pathology as $H$. pylori $(+)$ was a limitation of this study. ${ }^{28}$ In our study, patients diagnosed as H. pylori histologically were included in the study.

There are studies showing that chronic gastritis caused by H. pylori triggers a series of events in gastric carcinogenesis known as GA-IM-dysplasia-cancer sequence. ${ }^{29}$ In addition, there are studies stating that IM leads to bacterial overgrowth in colon and contributes to CRC..$^{30}$ Therefore, IM associated with $H$. pylori may increase colorectal carcinogenesis. Yan et al. ${ }^{31}$ found that IM increases CRC. In our study, a statistically significant relationship was found between IM and the risk of CRC in the presence of $H$. pylori. Considering the H. pylori-associated cancer sequence, ${ }^{29}$ we can explain the fact that the risk of CRC does not increase in the group of patients with IM who do not have H. pylori, although GA occurs before IM. Prolonged exposure to H. pylori increases gastrin levels. ${ }^{32}$ Hypochlorhydria caused by long-lasting hypergastrinemia and chronic GA may disrupt acid-sensitive microflora and increase the risk of CRC. ${ }^{32}$ In addition, increased hypergastrinemia in GA cases may lead to increased intraluminal ammonia and increased systemic inflammation, which can trigger intracellular tumor mechanisms. ${ }^{25}$ Lee et al. ${ }^{33}$ found that $H$. pylori and especially $H$. pylori positivity in patients with GA increased the risk of CRC. Gastrin has a trophic effect on epithelial cell growth and proliferation that may contribute to colorectal carcinogenesis, which is likely to increase the risk of CRC. ${ }^{34}$ In a prospective study, Thorburn et al. ${ }^{34}$ found that increased serum gastrin levels increased the risk of CRC. Kikendall et al. ${ }^{35}$ found that increased serum gastrin level did not increase the risk of CRC. In our study, patients with GA had significant H. pylori positivity and a significant correlation was found between GA level and CRC. In addition, increased risk of CRC in patients with GA without $H$. pylori suggests the possibility that hypergastrinemia may be the precursor of CRC other than H. pylori. Limitations of the study include retrospective nature and the inability to question environmental factors such as obesity and smoking, which may increase the risk of CRC in patients. The advantages of the study include the diagnosis of $\mathrm{H}$. pylori by histological diagnosis, which is the gold standard, the inclusion of hyperplastic polyps other than neoplastic colon polyps and the examination of 
Sydney criteria together with colon polyps. As a result of the study, it was determined that H. pylori did not increase the risk of colon hyperplastic polyps, adenomatous polyps, but increased the risk of malignant polyps in association with IM. In the presence of GA, there is also a statistically significant relationship between colon malignant polyps regardless of the presence of $H$. pylori. In the light of the data obtained in this study, patients with GA and patients with H. pylori and IM should be followed-up more closely for malignant colon polyps.

\section{Ethics}

Ethics Committee Approval: The study was approved by the Clinical Research Ethics Committee of Ordu University Faculty of Medicine (approval no: 2019-19, date: 7/2/2019). Informed Consent: Informed consent form was obtained from patients for surgical intervention and subsequent care, necessary permissions were obtained for the use of their data.

Peer-review: Internally peer-reviewed.

\section{Authorship Contributions}

Surgical and Medical Practices: Ç.A., Concept: Ç.A., Ö.Ö., Design: Ç.A., Data Collection or Processing: Ç.A., Ö.Ö., Analysis or Interpretation: Ç.A., Ö.Ö., Literature Search: Ö.Ö., Writing: Ç.A.

Conflict of Interest: No conflict of interest was declared by the authors.

Financial Disclosure: The authors declared that this study received no financial support.

\section{References}

1. Jemal A, Siegel R, Xu J, Ward E. Cancer statistics, 2010. CA Cancer J Clin 2010;60:277-300.

2. Fleming M, Ravula S, Tatishchev SF, Wang HL. Colorectal carcinoma: pathologic aspects. J Gastrointest Oncol 2012;3:153-173.

3. Jass JR. Hyperplastic-like polyps as precursors of microsatellite-unstable colorectal cancer. Am J Clin Pathol 2003;119:773-775.

4. Marschall BJ, Warren JR. Unidentified curved bacilli in the stomach of patients with gastritis and peptic ulceration. Lancet 1984;1:1311-1315.

5. Suerbaum S, Michetti P. Helicobacter pylori infection. N Engl J Med 2002;347:1175-1186.

6. Malfertheiner P, Megraud F, O'Morain C, Bazzoli F, El-Omar E, Graham D, Hunt R, Rokkas T, Vakil N, Kuipers EJ. Current concepts in the management of Helicobacter pylori infection: the Maastricht III Concensus Report. Gut 2007;56:772-781.

7. Price AB. The Sydney System: histolological division. J Gastroenterol Hepatol 1991;6:209-222.

8. Georgopoulos SD, Papastergiou V, Karatapanis S. Current options for the treatment of Helicobacter pylori. Expert Opin Pharmacother 2013;14:211223.

9. De Martel C, Ferlay J, Franceschi S, Vignat J, Bray F, Forman D, Plummer M. Global burden of cancers attributable to infections in 2008: a review and synthetic analysis. Lancet Oncol 2012;13:607-615.
10. Hong SN, Lee SM, Kim JH, Lee TY, Kim JH, Choe WH, Lee SY, Cheon YK, Sung IK, Park HS, Shim CS. Helicobacter pylori infection increases the risk of colorectal adenomas: cross-sectional study and meta-analysis. Dig Dis Sci 2012;57:2184-2194

11. Siddheshwar RK, Muhammad KB, Gray JC, Kelly SB. Seroprevalence of Helicobacter pylori in patients with colorectal polyps and colorectal carcinoma. Am J Gastroenterol 2001;96:84-88.

12. Breuer-Katschinski B, Nemes K, Marr A, Rump B, Leiendecker B, Breuer N Goebell H. Helicobacter pylori and the risk of colonic adenomas. Colorectal Adenoma Study Group. Digestion 1999;60:210-215.

13. Boyle P, Langman JS. ABC of colorectal cancer: Epidemiology. BMJ 2000;321:805-808.

14. Nagy R, Sweet K, Eng C. Highly penetrant hereditary cancer syndromes. Oncogene 2004;23:6445-6470.

15. Peek RM Jr, Blaser MJ. Helicobacter pylori and gastrointestinal tract adenocarcinomas. Nat Rev Cancer 2002;2:28-37.

16. Mbulaiteye SM, Hisada M, El-Omar EM. Helicobacter Pylori associated global gastric cancer burden. Front Biosci (Landmark Ed) 2009;14:14901504.

17. Thomson JM, Hansen R, Berry SH, Hope ME, Murray GI, Mukhopadhya I, McLean MH, Shen Z, Fox JG, El-Omar E, Hold GL. Enterohepatic helicobacter in ulcerative colitis: potential pathogenic entities? PLoS One 2011;6:e17184.

18. Hansen R, Thomson JM, Fox JG, El-Omar EM, Hold GL. Could Helicobacter organisms cause inflammatory bowel disease? FEMS Immunol Med Microbiol 2011;61:1-14.

19. Wang YK, Kuo FC, Liu CJ, Wu MC, Shih HY, Wang SS, Wu JY, Kuo CH, Huang YK, Wu DC. Diagnosis of Helicobacter pylori infection: Current options and developments. World J Gastroenterol 2015;21:11221-11235.

20. Buso AG, Rocha HL, Diogo DM, Diogo PM, Diogo-Filho A. Seroprevalence of Helicobacter pylori in patients with colon adenomas in a Brazilian university hospital. Arq Gastroenterol 2009;46:97-101.

21. Fujimori S, Kishida T, Kobayashi T, Sekita Y, Seo T, Nagata K, Tatsuguchi A, Gudis K, Yokoi K, Tanaka N, Yamashita K, Tajiri T, Ohaki Y, Sakamoto C. Helicobacter pylori infection increases the risk of colorectal adenoma and adenocarcinoma, especially in women. J Gastroenterol 2005;40:887893.

22. Brim H, Zahrf M, Laiyemo AO, Nouraie M, Pérez-Pérez GI, Smoot DT, Lee E, Razjouyan H, Ashktorab H. Gastric Helicobacter pylori infection associates with an increased risk of colorectal polyps in African Americans. BMC Cancer 2014;14:296.

23. Håkanson R, Sundler F. Trophic effects of gastrin. Scand J Gastroenterol Suppl 1991;180:130-136.

24. Strofilas A, Lagoudianakis EE, Seretis C, Pappas A, Koronakis N, Keramidaris D, Koukoutsis I, Chrysikos I, Manouras I, Manouras A. Association of Helicobacter pylori infection and colon cancer. J Clin Med Res 2012;4:172-176.

25. Zhao YS, Wang F, Chang D, Han B, You DY. Meta-analysis of different test indicators: Helicobacter pylori infection and the risk of colorectal cancer. Int J Colorectal Dis 2008;23:875-882.

26. Wang F, Sun MY, Shi SL, Lv ZS. Helicobacter pylori infection and normal colorectal mucosa-adenomatous polyp-adenocarcinoma sequence: a metaanalysis of 27 case-control studies. Colorectal Dis 2014;16:246-252.

27. Sonnenberg A, Genta RM. Helicobacter pylori is a risk factor for colonic neoplasms. Am J Gastroenterol 2013;108:208-215.

28. IARC Working Group on the Evaluation of Carcinogenic Risks to Humans. Biological agents. Volume 100 B: A review of human carcinogens. IARC Monogr Eval Carcinog Risks Hum 2012;100:1-441.

29. Correa P. Human gastric carcinogenesis: a multistep and multifactorial process--First American Cancer Society Award Lecture on Cancer Epidemiology and Prevention. Cancer Res 1992;52:6735-6740. 
30. Evenepoel P, Claus D, Geypens B, Maes B, Hiele M, Rutgeerts P, Ghoos $\mathrm{Y}$. Evidence for impaired assimilation and increased colonic fermentation of protein, related to gastric acid suppression therapy. Aliment Pharmacol Ther 1998;12:1011-1019.

31. Yan Y, Chen YN, Zhao Q, Chen C, Lin CJ, Jin Y, Pan S, Wu JS. Helicobacter pylori infection with intestinal metaplasia: An independent risk factor for colorectal adenomas. World J Gastroenterol 2017;23:1443-1449.

32. Ciccotosto GD, McLeish A, Hardy KJ, Shulkes A. Expression, processing, and secretion of gastrin in patients with colorectal carcinoma. Gastroenterology 1995;109:1142-1153.
33. Lee JY, Park HW, Choi JY, Lee JS, Koo JE, Chung EJ, Chang HS, Choe J, Yang DH, Myung SJ, Jung HY, Yang SK, Byeon JS. Helicobacter pylori infection with atrophic gastritis is an independent risk factor for advanced colonic neoplasm. Gut Liver 2016;10:902-909.

34. Thorburn CM, Friedman GD, Dickinson CJ, Vogelman JH, Orentreich N, Parsonnet J. Gastrin and colorectal cancer: A prospective study. Gastroenterology 1998;115:275-280.

35. Kikendall JW, Glass AR, Sobin LH, Bowen PE. Serum gastrin is not higher in subjects with colonic neoplasia. Am J Gastroenterol 1992;87:13941397. 